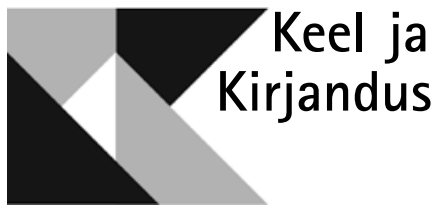

\title{
LÕPUTA JA LÕPUTU RAHVAJUTT
}

\section{Juhatuseks rahvajuttude erinumbri lugejale}

RISTO JÄRV

1.

ugustis 2005 olin tudengitega välitöödel Eesti servas, Setomaal, kogu-
mas muinasjutte, et talletada vana jutupärimust, nii nagu seda selleks
hetkeks teati ja mäletati. Meie eesmärgiks oli leida ja jäädvustada lugusid, iseäranis muinasjutupärimuse valdajailt. Eri alažanris muinasjuttudest tekitasid rahvaluulekogujais ikka elevust nn lõputa lood; neist kuulaja hanitamiseks mõeldud lugu „Valge härg” andis seto jutuvestjaid tutvustavale DVD-plaadile ka nime (VH 2009).

Lõputa lugude sarnane on ka ekspeditsioonil kuuldud ahelmuinasjutt hernestest, mis ei lähe kotti. Jutu originaalsalvestus koos transkriptsiooniga on ilmunud kogumikus „Valge härg” (VH 2009: 32, lugu 23). Esitan siinkohal loo eestikeelse tõlke:

Tüdruk läks aeda ja hakkas herneid korjama. Korjas herned ära ja ütles hernestele, et: „Minge kotti!”

Aga herned ei läinud kotti.

Tüdruk hõikas hiirt: „Hiir, tule söö herned ära, sest herned ei lähe kotti!” Hiir tuli, aga herneid ära ei söönud.

Tüdruk hõikas kassi: „Kass, tule söö hiir ära, sest hiir ei söö herneid ära ja herned ei lähe kotti!" 
Aga kass ei puutunud hiirt.

Tüdruk hõikas koera: „Koer, tule püüa kassi, sest kass ei püüa hiirt, hiir ei söö herneid ära ja herned ei lähe kotti!”

Aga koer kassi ei puutunud.

Siis hõikas tüdruk vitsa: „Vitsad, tulge pekske koera, sest koer ei püüa kassi, kass ei söö hiirt, hiir ei söö herneid ja herned ei lähe kotti!”

Aga vits ei peksnud koera.

Tüdruk hõikas kitse: „Kits, kits, tule ruttu, tule söö vitsad ära, sest vitsad ei peksa koera, koer ei puutu kassi, kass ei söö hiirt, hiir ei söö herneid, ja herned ei lähe kotti!"

Noh, kits tuleb, aga vitsa ära ei söö.

Siis tüdruk hõikas hunti: „Hunt, hunt, tule söö kits ära, sest et kits ei söö vitsa, sest vits ei peksa koera, koer ei aja kassi taga, kass ei söö hiirt, hiir ei söö herneid ja herned ei lähe kotti!"

Aga hunt ei puutunud kitse.

Siis tüdruk hõikas karu: „Karu, tule ruttu! Tule söö hunt ära, sest hunt ei söö kitse ära, kits ei söö vitsa, vits ei peksa koera, koer ei aja kassi taga, kass ei söö hiirt ära, hiir ei söö herneid ja herned ei lähe kotti!"

Siis tuli karu, murdis hundi maha. Aga hunt sõi kitse ära, kits sõi vitsa ära, vits peksis koera, koer ajas kassi taga, kass sõi hiire ära, hiir sõi herned ära, herned läksid kotti ja tüdruk läks koju.

ERA, MD 559 (7) < Setomaa, Meremäe v, Obinitsa k - R. Järv, E. Kubu, R. Reinaus < Terje Lillmaa (2005)

\section{2.}

Rahvusvahelises rahvajuttude tüübikataloogis on nii lõputa lood kui ka ahelmuinasjutud jt sarnased lood klassifitseeritud kataloogi viimasesse alaliiki, vormelmuinasjuttude alla (ATU 2000-2399). Juri Lotman on nimetanud sellist kumulatiivset muinasjuttu „narratiivsusprintsiibi puhtaimaks kehastuseks" (Lotman 1990 [1981]: 327). Alaliigi rahvusvaheliseks terminiks on ahelmuinasjutt (ingl chain tale) ja kumulatiivne muinasjutt (ingl cumulative/ accumulative tale, vt Wienker-Piepho 1993: 1194).

Mõned aastad tagasi sai sarnase ahelülesehitusega laul „Tibupoeg Pio” väga populaarseks lauluhitiks Itaalias, nii et räägiti lausa „massipsühhoosist, mis oli haaranud kogu Itaalia” (vt lähemalt Zavjalova 2014). Ka selles laulus ilmuvad tegelastena üha suuremad loomad, kuni saabub fataalne lõpp. Laulu mõjuvuse põhjuseks on peetud ennekõike meeldejäävat rütmi ning imetlusväärset ja maagilist, loitsudega võrreldavat struktuuri (Zavjalova 2014: 40).

Eesti rahvajuttudest on vormelmuinasjutud üsna vähe käsitletud aines. Aarne-Thompson-Utheri rahvusvahelise rahvajuttude tüübikataloogi (ATU) järgi võib eespool viidatud jutu klassifitseerida jututüüpi 2030, mis ingliskeelsena kannab nimetust „The Old Woman and Her Pig” („Vanaeit ja siga”). Lugu kujutab järjestikuse struktuuriga ahelat: loetletakse rida tegelasi väiksemast suuremani, kuni toimub imelik hüpe, argielu loogikast põikuv põige. Vladimir Propp on sõnastanud, et pärast tegevuse või elementide kordamist lõpeb aheljutt „mingi lõbusa katastroofiga” (Propp 1998: 253). Sarnase variandi leiab rahvajututöötluste kogumikust „Sada saarelehte, tuhat toomelehte” (SSTT 2010 [1968]: 165-167). 
Eespool toodud loo jutustaja Terje Lillmaa tutvustas meie esimesel kohtumisel 2004. aastal ennast kohe muinasjutuvestja Heino Sõrmuse sugulase ning Vasla külast pärit jutuvestja Rannula Mahti lapselapsena (vt lähemalt Järv 2008: 229-230, ka Meier 2012: 53 jj). Paljude välitöödel kohatud erakordsete jutuvestjate hulgas oli väga eriline ka Terje. Muljetavaldav oli nii tema repertuaari rikkalikkus kui ka perekondlik jutuvestmine - tema lasteltki kuulsime mõne loo. Veelgi enam, kuivõrd mitmel aastal toimunud ekspeditsioonide eesmärk oli talletada pärimust Setomaa muinasjutuvestjatelt ning koguda teateid endisaegsest jutuvestmisest ja mälestusi omaaegsetest jutustajatest, olid kogumistöö sihtrühmaks ning kohalike poolt juhatatuteks eelkõige vanemad inimesed, rahvaluulekogujatega ühevanune Terje Lillmaa oli ülejäänud külastatud jutuvestjatest märgatavalt noorem.

3.

Oskuslik jutuvestja on läbi aja olnud hinnatud. Richard Viidalepp toob oma väitekirjas Eesti jutustamistraditsioonist arhiivinäiteid XIX sajandist: rahvajutte vesteti tasuks öömaja eest (Viidalepp 2004 [1965]: 76-77). Soome rahvaluule arhiivi saadetud kogumisvõistluse kaastööde põhjal on Urpo Vento (1980: 97) kirjeldanud üht meeldejäävat saadetist, milles kujutatakse erilist jutuvestjat. Soomes tuli 1932. aastal Kesk-Pohjanmaal väga rasketes tingimustes elavate metsatööliste juurde kehvalt riietatud mees, kes palus pikemaks ajaks peavarju, lubades vastutasuks oma juttudega tööliste meelt lahutada. Lepiti kokku, et ta võib sinna jääda, kuid ei tohi seal rääkida üht juttu või nalja kaks korda. Ka tema töö oli metsatöölistega võrreldavalt raske, kestes järjestikuse jutuvestmisena 2-4 tundi päevas, puhkepäevadel koguni 10 tundi. (Korra jutuvestja ka kordas ennast ning vastavalt kokkulepitule arutati ühiselt, kas ta üldse saab jätkata; jutuvestja vabandas ennast kurnatusega, mille järel talle võimaldati lühike „enesetäiendamine” lähedalasuvas linnas.) Kui töö nelja kuu pärast lõppes, kogusid töömehed oma saadud palgarahast jutuvestjale kaabu sisse kokku nende endi palka ületava summa.

Selliste poeetiliste kirjelduste vastukaaluks tuuakse juba aastakümneid näiteid jututraditsiooni kadumisest. Nii näiteks olevat ratsionaalne maailmavaade „pannud hääbuma jutuvestmises avalduvad usundilised kujutelmad” või olevat jutustamise sotsiaalne sidusus kadunud seoses ühiste talutööde puudumisega, mille tõttu jutuvestmiskogukonnad on hääbunud, või siis väidetakse, et massimeedia on hävitanud suulise pärimuse, ometi võib kõigile neile tuua ka vastuväited (vt lähemalt Fischer s.a. [1987]). Samas pole jutuvestmine kuskile kadunud - kuigi pole enam selliseid ühiseid talutöiseid jutustamisi või kooskäimisi, nagu on kirjeldanud eri rahvastel Linda Dégh (1989 [1969]), on jutud ja jututeemad ikkagi alles. Endised süžeed võivad korduda uues kuues (Kõiva 1996: 174), kuulujutte võib pidada muistendi tänapäevaseks lühemaks esituseks (Kalmre 2007: 194) ning meedia on rahvajutustaja mallid üle võtnud (Kalmre 2012: 329). Jõudsalt püsib jutuvestmine kaasaja internetipärimuses (Roth 2013).

Loomulikult ei pea me rahvajuttude otsimiseks pöörduma ainult mineviku kuldsesse mälestusse. Ameerika uurija Sandra Stahl (Dolby) on aastakümneid tagasi väitnud, et iga tavalise inimese repertuaaris on vähemalt kolm- 
neli isikliku kogemuse juttu või isikukogemuse juttu (ingl personal experience story), mida ta kordab oma elu jooksul tõenäoliselt mitmeid kordi ning mis on sellisena folkloorsed (Stahl s.a. [1977]; Dolby 1989). Olulisi jutte võidakse taasjutustada mitmeid kordi ning see võib kuulajaile ikka ja alati olla huvitav, jutu võlu on sageli ennekõike selle esituses. Nii võib ühest jutustamisolukorrast teise korduv ja edasikanduv tekst, näiteks iga-aastasel sünnipäeval korratud lapsepõlvemeenutused, muutuda suisa rituaalseks, kandes endaga varjatult kaasas kõikide möödunud jutustamiskordade taustu ja tagamaid.

Eesti folkloristikas on isikulugude kirjeldamisel olnud teedrajav Mall Hiiemäe teos „Kodavere pajatused” (1978), milles ta väitis folkloristide jaoks samuti uut ainest avades, et mida vähem jutustaja toetub teadmusele konkreetsest ning mida enam enda ja teiste varasematele jutustustele, seda folkloorsem on jutt (Hiiemäe 1978: 63-64). Korduda võib ka juttude struktuur.

Rahvajutt ja jutustamine on oma olemuselt lõputu protsess, millest, tõsi küll, uurijad saavad fikseerida ainult üksikuid väga põgusaid hetki või nende hetkede heiastusi jutustajate mälus. Igal juhul võib jutuvestmist näha lõputu ahelana, milles varasemad kogemused ja nende talletamine annab aluse tuleviku rahvajuttudeks.

\section{4.}

Inimesele loomuomast viisi edastada infot lugude kaudu on saksa rahvajutuuurija Kurt Ranke 1967. aastal kirjeldanud sõnapaariga Homo narrans (Lehmann 2009: 59), mis on saanud laialdaselt kasutatavaks kinnisväljendiks, leides koha mitmete raamatute pealkirjades (nt Schmitt 1999; Niles 2010). Narratiivina vahendatud kirjeldus on palju tõhusam mis tahes õpetussõnadest.

Rahvajutus on koos kaks kihistust, mis on pealtnäha üksteisele vastandlikud: üks on analüütiline ja informeeriv, teine poeetiline ja kujutluspilti virgutav. Rahvajuttude poeetika võimaldab öelda väga erinevaid asju, samas kasutades oskuslikult kujundiloomet. Jutt aitab lisaks luua tegelikkuse omalaadse mudeli. Poeetiline kihistus loob maailma, mille puhul ei olegi ainutähtis tõde, vaid tõe ja esituse oskuslik kombineerimine. See viib meid argielust välja (vrd Järv 2010), ühtlasi aidates „inimest maailmas toime tulla” (Päär 1999: 221).

Sõna „rahvajutt” koosneb kahest lihtsast komponendist. Rahvas on muidugi kes tahes meist - „teiste seas ka meie!”, nagu on sõnastanud Alan Dundes oma kuulsas essees „Kes on rahvas?” (Dundes 2002 [1997]: 32]). Rahvajutu rääkija võib olla seega kes tahes meie ümber, nii nagu folkloorikandjad me oleme kõik. Jutt on mis tahes lugu, narratiiv.

Kultuuriteoorias ja mujal kasutatav mõiste narratiiv ongi ajendunud ennekõike varasemate folkloristide uurimustest. 1980.-1990. aastatel toimunud narratiivne pööre tõrjus senikestnud üldise tava püüda esitada kõike objektiivselt, ning erinevatel elualadel mööndi, et meie kultuuritajumine koosneb üksikutest seotud lugudest, lugude mõistmise kaudu saame maailma enda jaoks selgemaks (vt lähemalt nt Väljataga 2008). Omaette uurimisalana kujunes välja narratoloogia, mis lähtub eeldusest, et narratiivid osalevad „kogemuse ja taju maailmade" loomisel (vt nt Grišakova 2010: 7). Tõsielusündmuste puhul pole oluline juhtunu kui fakt, vaid sellele tähenduse andmine, mälus loodavad mustrid kujundavad kogemust ja järelikult selle jutustamist (vt nt Jaago 2010: 188-189). 
Suulise jutuvestmise eripära sunnib sõltuvalt kontekstist loo eelmisele esitusele midagi juurde panema, juttu arendama vastavalt kuulajate ootustele ja nende heakskiitu silmas pidades. Nii on ka tõsielusündmusi kajastavates juttudes tegelikkus tihti moondunud jutuvestmisolukordade jada kontekste ja meeleolusid järgides. Linda Dégh (2003 [1989]: 12) on välja toonud, et rahvajuttudele sarnaselt vahendavad ka elulood elukäigust ainult kilde, keskendudes nn kõrghetkedele - „positiivsetele või negatiivsetele tegudele ja nende tagajärgedele". Reaalsus on töödeldud ning läbinud nii rahvajutu tõe- kui ka väljendusprisma. Ehk siis: „Heale jutule pole tõde takistuseks” (vrd Kalmre 2003).

\section{5.}

Rahvajuttude poeetikat iseloomustavad mitmed tunnuslikud märksõnad, mis ilmekalt esinevad ka jutus „Herned ei lähe kotti”. Näiteks lihtsus ja meeldejäävus on need elemendid mitmete kõrval, mis iseloomustavad rahvajutte laiemalt. Kuigi tegelaskujusid on kirjeldatud loos päris palju, toimub nende vaheldumine selgelt ja loogiliselt. Ilmekalt toetavad rahvajuttude poeetikat taani uurija Axel Olriki poolt sajand tagasi välja toodud „eepilised seadused” (1992 [1921]). Rahvajutus esitatakse sageli ainest üsna lihtsalt, mis tuleneb selle peamisest esitusviisist suulisena. Paljud Olriki seadused (nii ka lihtsuse seadus, vt Olrik 1992: 42-43; § 58) on edukalt leitavad ka tänapäeval kogutavates rahvajuttudes, nagu näitavad Tartu Ülikoolis rahvajutukursuse käigus viimaste aastate jooksul üliõpilaste kogutud rahvajutud ja nende analüüsimine.

Žanrinõue. Pealtnäha ebaloogiline lõpp pole ei jutustaja eksitus ega tulene tema oskamatusest olukorda lahendada, vaid see on žanri sund. Nii jutu rääkija kui ka kuulaja peavad valdama jutu edukaks edastamiseks žanri koodi. Imemuinasjutt tõlgendab imeelemente loomulikuna, muistendeis osutub üleloomulik probleemiks. Kirjeldatud aheljutule ongi tunnuslik loo keskel olev murdepunkt, kus toimub absurdne pööre. Samas võib mõnedegi juttude puhul olla ebaloogilisus ka päris tavaline. Jutuvestja ei pane tähele loogikavastaseid eksimusi, ning tihtipeale ei märka neid ka kuulaja. Jutu tõde ega loogika ei pea kulgema kooskõlas ratsionaalse mõtlemisega. Lugu on see, mis luuakse suulisena kohapeal, ja on ainuõige just sellisena. Uku Masing on sõnastanud boreaalseid samastusmüüte uurides ilmekalt nende kahe loomelaadi vastanduse: „Selliseid vigu teeb jutustaja, töötleja püüab neid vältida” (Masing 2011 [1986]: 179). Samasuguste mõtetega tuleb ka rahvajutule läheneda, sellele ei saa kohaldada kirjakunsti reegleid.

Seos reaalse eluga. Rahvajutud on ikka seotud meie tegelikkusega, sellega, millega me kokku puutume. Reaalsus võib ilmneda nii otse kui ka ülekantud tähenduses. Põllult võetud herneste kottipanek ning nendega seotud töö oli tavaline reaalsus varasemas ühiskonnas. Vahetult kujutavad elu ennekõike mõned jutuliigid, nagu pajatus või memoraat, aga ka muistend ning isegi muinasjutt. Mairi Kaasik on rahvaluulekoguja Artur Vigla poolt kirja pandud Hans Küivitsa muinasjutte analüüsides näidanud, et traditsiooniliste imeelementide kõrvale on tema lugudes lisandunud telegraaf, raudtee ja auto (Kaasik 2010: 83-84). Nii pole ime, et kui endisaegsest rahvajutumaailmast 
leiame talutüdruku koos tavapäraste talutööde ja -esemetega, siis tänapäeva koolilaste kirja pandud muinasjuttudes on peategelasteks arvutid. Kui Rakvere teater tõi mõned aastad tagasi lavale muinasjutu „Tuhkatriinu”, millega kaasnes üleskutse saata uusi muinasjutte, tuli vastuseks sadu omaloomingulisi lugusid, kus traditsiooniline süžee on sujuvalt paigutatud tänapäeva olmelisse konteksti - seejuures on muinasjutu žanritunnused kenasti püsima jäänud.

Ühes väikeses linnas elas üks poiss koos oma kasuvendadega. Vennad mängisid kogu aeg arvutis ja Priidut sinna ei lasknud. Iga päev mõtles Priidu, et tahan kah endale vähemalt I-Padi.

Või siis:

Kui isa ära läks, pidi Tuhkatriinu kohe koristama hakkama, õed hakkasid aga arvutis mängima. Järgmisel päeval tuli võõrasemale kiri, et ta on oma lastega kutsutud peole (RT Tuhkatriinu).

Sõnum. Selge on see, et igal jutustamisel on erinevad eesmärgid. Osalt on need eesmärgid kodeeritud jutužanride abil, kuid nii nagu vanasõnadel (vrd Krikmann 1974), pole ka rahvajuttudel üht kindlat tähendust ega ainsat sõnumit. Sellised isikujutud võivad edasi anda nii traditsioone kui ka väärtushinnanguid (Kõiva 2003: 90). Jutu sõnum sõltub sellest, kes seda räägib ning kellele ja milleks ta seda räägib, sõnum võib olla peidetud kas jutu sisse või hoopis sellele järgnevasse või eelnevasse kommentaari. Jutt võib olla lihtsalt sõnumi edasiandmise abivahend. Paraku jääb see oluline teave rahvajuttude kogumisel ja kirjapanemisel enamasti fikseerimata, kuid on ometi tuletatav ning põhjalikult analüüsitav (vrd Dolby 1989: 83-117).

\section{6.}

Ilmselt kõige tavalisem rahvajutuliik on isikukogemuse juttude kõrval see, mida tähistatakse halvakõlaliste sõnadega kuulujutt või klatš. Just argielu jutud, pajatused ja arutlused kogukonna sündmustest, aga ka erinevad mälestused on inimeste rahvajutuainese põhiosa (vt nt Schenda 1993: 265-266). Narratiivi vormi rüütatu põhjal kujunevad välja stereotüüpsed arusaamad teistest ja nendega suhtlemine. Eesti esimene folkloristikaprofessor Walter Anderson uuris juba 1921. aastal Tartus levinud kuulujuttu Marsi plahvatamisest, kasutades muuhulgas ajalehtedes avaldatud uudiseid (Anderson 2005 [1925, 1926]).

Rahvajuttude klassikalisteks žanrideks hinnangulise väärtusskaala „teises servas" on muinasjutt, muistend ja müüt. Müüdi kajastusi võib leida meil pigem vaid loomislugudes ning näiteks hiiu- ja vägilasmuistendeis, kuid sarnaselt teiste maadega on muinasjutud ning muistendid paljukogutud žanrid, mida on seepärast ka palju käsitletud. Kindlasti ei tähenda õigustatud kriitika rahvaluulekogude seniste formeerimistendentside kohta (vt nt Beyer 2011), et neid ei peaks analüüsima. Folkloristikas varasemal ajal tavalise tekstikeskse lähenemise ja staatilise vaatluse asemel on tänapäeval levinud folkloori käsitlemine protsessina (vrd Honko 1998), nii on folkloor pigem suhtluse ja 
esituse ning erinevate esituspraktikate looming. Arhiivi on hakatud nägema tekstikogumina, kus tekstile võib luua konteksti just talletuste järjepidevus (Anttonen 2013). Loomulikult pole arhiiv seejuures sündinud iseenesest, vaid just teatud valikute tulemusena, läbi teatava sõela. Folkloorikogud koondavad endas suulise pärimuse representatsioone ning sellisena iseloomustab neid paratamatult valikulisus, osaliste tõdede esitamine ja allegoorilisus (vrd Clifford 1986).

On mitmeid olulisi kvaliteete, mis teevad arhiivi just iseäranis oluliseks allikmaterjaliks. Suulisele pärimusele on üldomane varieerumine, ühest küljest on ka jutuvestja pagasiks kõik varem kuuldud jutuvariandid, teisest küljest, nagu öeldud, teeb jutu kuulajale huvitavaks just see jutustajapoolne lisanüanss, ütlemisviis, tundetoon või ka aimatav autobiograafiline vihje. Folkloorse loomemeetodi omapära, suulise ja korduva esituse eripärased nüansid, situatsioonisidusus teevad sellest põneva uurimisobjekti. Varieeruvad lood on need, mis annavad arhiivi mõistes meile terviku. See on kirjanduse ja rahvaluule vaheline põhimõtteline erinevus, et viimases on varieerumine oluline. Jutu-uurijail on siin abivahendiks tüübi- ja motiivikataloogid, mille abil sarnaseid lugusid leida.

Samas on tekstilise uurimise puhul rahvajutu „vangistamine kirjapilti” nagu herne püüdmine kotti, kus tuleb rakendada teatud vägivaldsust. Kui vaadata loo „Herned ei lähe kotti” videotalletust, näeme, kuidas jutustaja kaasa elab, žestikuleerib, teatud hetkedel sõnu otsib, loetelu korrates elavneb. Silmatorkav on seegi, kui kiire, loomulik ja valutu on kirjapildis esmahetkel „ebaloogiline” üleminek reaalsuses võimatule edasisele tegevusreale pärast seda, kui karu on hundi ära söönud. Nii on vormeljuttude kohta märgitud, et „jutust tähtsam on selle esitus” (Ashliman 2008: 176). Seega tuleb edasises meeles pidada, et toetumine tekstikujul kirjapanekutele kui esituse representatsioonidele seab igal juhul teatud piirangud.

\section{7.}

Keele ja Kirjanduse rahvajuttude teemanumbrit koostades pöördusin paljude folkloristide poole, püüdes nende uurimisalast lähtuvalt hõlmata nii erinevaid rahvajutužanre kui ka erinevaid ajaperioode ning olulisi teemasid. Teema kõnetas paljusid uurijaid, ent ajakirja piiratud mahu tõttu jäävad laekunud kaastöödest mitmed ootama ilmumisjärge järgmistes numbrites ning ka teistes väljaannetes.

Ülo Valk näitab oma artiklis, et üks rahvajutu tuumžanre - muistend - ei saa olla valmis žanr, selle realiseerumiseks on vaja mingit konteksti, lihtne kirjapanek ei tarvitse olla piisav muistendi mõistmiseks. Muuhulgas puudutab Valk olulist autentsusteemat, seades küsimuse alla viisi, kuidas varasematel aegadel on arhiivitöötajad oma meelsust avaldanud, tehes hinnangulisi märkusi algkäsikirjale.

Mare Kalda vaatleb kolme arhiivitöös keskset mõistet - žanr, tüüp ja motiiv -, jõudes rahvajutu-uurimise aktuaalse küsimuseni. Ise suure aardemuistendite alarühma tüpoloogia koostanuna käsitleb autor arhiivitöö ees seisja praktilisi probleeme. Materjali edasise analüüsi seisukohalt on oluline autori märkus: arhiivimaterjalil põhineva tüpoloogia koostamine pole mitte uurimise 
lõpptulemus, vaid alles edasise töö tarvilik lähtepunkt, samas võib just tüpoloogias peituda interpreteerimiseks olulisi küsimusi.

Merili Metsvahi interpreteerib rahvaluules tuntud muistendisüžeed õe ja venna abielu tagajärjel veepõhja uppunud ehitisest. Folkloristlikku analüüsi arheoloogia andmetega põimides järeldab autor, et kuigi muistenditeema pole tänapäeval enam aktuaalne, selgitab see süžee erinevate ühiskonnakihtide erineval maailmanägemisel põhinevaid pingeid, andes juttude kaudu signaali kriitikast teistsuguste kommetega sissetulijate kohta.

Helen Kõmmus analüüsib müüdiainest ning loob seose müüdilise kihi ning reaalelulise kangelase vahele. Hiiumaa vägilasmuistendite kangelase Leigri kujunemislugu analüüsides selgineb temas koondkuju saare maastiku kujundajast kultuurheerosest ning võimekast teadjamehest. Huvitavana selgub, et Leigri-nimelistest taludest on mitme sugupõlve jooksul kerkinud eriliste võimetega ravitsejaid ja tarku.

Kärri Toomeos-Orglaan käsitleb kirjaoskuse küsimust setode kultuurikirjelduses ning kirjakultuuri mõju nende jutupärimusele. Huvipakkuv on detail, et võrreldes muu Eestiga on Seto ala kirjanduslaenuliste juttude osakaal traditsioonis peaaegu sama mis ülejäänud Eestis - ligi kümnendik -, seega on õigustatud küsimus, kuidas mõtestada seda osa arhiivimaterjalist, mis toetub kirjalikele allikatele.

Inge Annomi artikkel viib meid Eestist välja Lätisse Lutsimaa kadunud eestlaste hõimu juurde. Multikultuurses keskkonnas elanud Lutsi eestlaste jutuvara on mõjutanud eri rahvaste jututraditsioon. Autor pöörab põhjalikumat tähelepanu olulisematele selle piirkonna jutustajatele. Materjali põhjal selgub, et osa Lutsi eestlaste tüübiredaktsioone on sarnased Setomaa variantidega, mis võib seletada vähemalt ühe osa Lutsi maarahva pärinemist LõunaEestist.

Mall Hiiemäe analüüsib pärimusprotsessi jälgides välitöödel talletatud jutustaja Puu Jaagupiga seonduvat jutupärimust, leides, et isikuga seotud rahvajuttude eluiga on lausa sadakond aastat. Autor juhib taaskord tähelepanu reaalse elu ja fantaasiamaailma tarvilikule sümbioosile, milleta valetamisjutud poleks elavas jutuvestmistraditsioonis püsida saanud.

Liisi Laineste artikkel toob rahvajutuainese kaasaja elektroonilisse maailma, tõmmates ühendava kaare „vanade” naljade meenutamiseni tänapäevases veebikeskkonnas. Üldistavalt kõigi ajakirjanumbri artiklite kohta kõlab autori tõdemus, et sarnaselt mis tahes rahvajutuga võimaldab ka anekdoot illustreerida, kommenteerida ja korrastada meid ümbritsevat maailma.

Eesti Rahvaluule Arhiivist pärinevatele tekstinäidetele viitamisel on järgitud traditsioonilist folkloristika viitamissüsteemi. Arhiivitekstid on esitatud väheste redigeeringutega, kohendatud on interpunktsiooni. Ajakirja formaat tingib selle, et me ei saa kasutada ei audio- ega ka videonäiteid, mis võiks olla tänapäevase jutuvestmise analüüsi täiendavad võimalused. Nii baseeruvad artiklid valdavalt „kirjapilti vangistatud suulistel esitustel”. Samas ei tarvitse jutustamishetke ehedust alati aidata tajuda ka video, just vahetult kogetu võib olla väärtus omaette. Setomaa rahvajutu-välitööde algusest mäletan ülieredalt ühe vana mehe räägitud lugu, kuidas ta lapsena oli tunnistajaks metsatööliste kohtumisele seletamatu elamusega, mida saatsid väikse koera kohutav haukumine ja lindude õõvastavad hääled, okste vali ragin ning seejärel nähtud pilt, kuidas läbi metsa liikus heinasaad - millest järgmisel 
päeval vaatama minnes polnud lumel mingeid jälgi. Liikuv heinasaad on eesti folklooris traditsiooniline kuradi esinemiskuju ning meie rahvausundis üks iseloomulikumaid kuradi esinemisvorme (Valk 1998: 172-174). Sel hetkel, kui jutuvestja mulle seda lugu rääkis, tundsin selgelt, et palaval suvepäeval läks külmemaks ning ritsikate sirin vaikis. Videos midagi taolist hiljem ei taju.

Elus kogetud argine ja igapäevane rahvajutt võib mõjuda meeldiva kirsina tordil, aga see võib olla ka õhtu piduroaks. Olgu siis selleks mõni juhuslikult kuuldud jutt või ootamatult kohatud vestluskaaslane, kes räägib just sellise loo, mida oli sel hetkel vaja. Loodetavasti aitab selliste lugude märkamisele ja mõtestamisele kaasa ka Keele ja Kirjanduse erinumber.

Ajakirja erinumbri valmimist on toetanud Haridus- ja Teadusministeeriumi uurimisprojektid IUT22-4 „Folkloor kultuurilise kommunikatsiooni protsessis: ideoloogiad ja kogukonnad” ja IUT2-43 „Traditsioon, loovus ja ühiskond: vähemused ja alternatiivsed diskursused" ning Euroopa Liit Euroopa Regionaalarengu Fondi kaudu (Kultuuriteooria Tippkeskus).

\section{Kirjandus}

A n d e r s o n, Walter 2005 [1925, 1926]. Die Marspanik in Estland 1921. - Studies in Estonian Folkloristics and Ethnology. A Reader and Reflexive History. Tartu: Tartu University Press, lk 169-200.

A n t t o n e n, Pertti 2013. Lost in intersemiotic translation? The problem of context in folk narratives in the archive. - Arv. Nordic Yearbook of Folklore, lk 153-170.

A s h li m a n, D. L. 2008. Sub Chain Tale. - The Greenwood Encyclopedia of Folktales and Fairy Tales. I. Toim Donald Haase. Westport, Connecticut: Greenwood. ATU = Hans-Jörg Uther 2004. The Types of International Folktales. A Classification and Bibliography. Based on the System of Antti Aarne and Stith Thompson. Part I: Animal Tales, Tales of Magic, Religious Tales, and Realistic Tales, with an Introduction. (FF Communications 284.) Part II: Tales of the Stupid Ogre, Anecdotes and Jokes, and Formula Tales. (FF Communications 285.) Part III: Appendices. (FF Communications 286.) Helsinki: Suomalainen Tiedeakatemia.

B e y e r, Jürgen 2011. Kas folkloristid uurivad rahva jutte? - Vikerkaar, nr 1-2, lk 52-65.

Clifford, James 1986. Introduction. Partial truths. - Writing Culture. The Poetics and Politics of Ethnography. Toim J. Clifford, Geoge E. Marcus. Berkeley-Los Angeles-London: University of California Press, lk 1-26.

D é g h, Linda 1989 [1969]. Folktales and Society: Story-Telling in a Hungarian Peasant Community. Bloomington: Indiana University Press.

D é g h, Linda 2003 [1989]. Ilu, jõukus, võim. Naiste karjäärivõimalused rahvajuttudes, muinasjuttudes ja tänapäeva meedias. - Mäetagused. Hüperajakiri, nr 23, lk 9-55; http://www.folklore.ee/tagused/nr23/degh.pdf (18. VIII 2015).

D o l b y, Sandra 1989. Literary Folkloristics and the Personal Narrative. Bloomington: Indiana University Press.

D u n d e s, Alan 2002 [1997]. Kes on rahvas? - A. Dundes, Kes on rahvas? Valik esseid folkloristikast. Toim Ülo Valk, Evelin Lepp. Tallinn: Varrak, lk 11-32.

Fis cher, Helmut s.a. [1987]. Argijutustamine tänapäeval: tekstide kogumise ja töötlemise problemaatikast. VTK raamat. http://www.folklore.ee/seminar (18. VIII 2015). 
G r i š a k ov a, Marina 2010. Saateks. - Jutustamise teooriad ja praktikad. Toim M. Grišakova, Katrin Kangur. Tartu: Tartu Ülikooli Kirjastus, lk 7-9.

H i i e m ä e, Mall 1978. Kodavere pajatused. Kujunemine ja koht rahvajututraditsioonis. Tallinn: Eesti Raamat.

H o n k o, Lauri 1998 [1990]. Folklooriprotsess. - Mäetagused. Hüperajakiri, nr 6, lk 56-84; http://www.folklore.ee/tagused/nr6/honko.htm (18. VIII 2015)

J a a g o, Tiiu 2010. Sündmus - mis-juhtus-küsimus tõsielulugudes. - Jutustamise teooriad ja praktikad. Toim Marina Grišakova, Katrin Kangur. Tartu: Tartu Ülikooli Kirjastus, lk 183-204.

Järv, Risto 2008. Muinasjutuline Setumaa. - Setumaa kogumik. 4. Uurimusi Setumaa loodusest, ajaloost ja folkloristikast. Tallinn: Ajaloo Instituut, MTÜ Arheoloogiakeskus, lk 220-245.

J ä r v, Risto 2010. Muinasjutt ja turismireis. - Keel ja Kirjandus, nr 8-9, lk 628638.

K a a s i k, Mairi 2010. Aja kategooria eesti imemuinasjuttudes. Magistritöö. Tartu Ülikooli filosoofiateaduskond. http://hdl.handle.net/10062/15229 (18. VIII 2015).

K a l m r e, Eda 2003. Heale jutule pole tõde takistuseks. Jan Harold Brunvandi linnalegendid 20 aastat hiljem. - Mäetagused. Hüperajakiri, nr 23, lk 185-202; http://www.folklore.ee/tagused/nr23/brunvand.pdf (18. VIII 2015).

K a l m r e, Eda 2007. Ühe sõjajärgse kuulujutu mitmekülgsest tähendusruumist. Paar sammukest XXIII. Eesti Kirjandusmuuseumi aastaraamat 2006. Toim Mare Kõiva, Taive Särg. Tartu: Eesti Kirjandusmuuseumi Teaduskirjastus, lk 191-212.

K a l m r e, Eda 2012. Väikese rahva „suured lood” - rahvajuttude kaudu konstrueeritud eneseesitlusest. - Keel ja Kirjandus, nr 5, lk 321-334.

K r i k m a n n, Arvo 1974. On Denotative Indefiniteness of Proverbs. Remarks on Proverb Semantics 1. Tallinn: S.n.

Kõ i v a, Mare 1996. Siis astu aknalauale. - Mängult-päriselt. (Tänapäeva folkloorist II.) Toim M. Kõiva. Eesti Rahvaluule Arhiiv, Eesti Keele Instituut, lk 166-188. http://www.folklore.ee/rl/pubte/ee/cf/mjap/mare.html (18. VIII 2015).

Kõ i va, Mare 2003. Lugu suurest lumesajust. Rootsieestlaste lood Nõukogude Eestist. - Mäetagused. Hüperajakiri, nr 23, lk 56-94; http://www.folklore.ee/ tagused/nr23/lumetorm1.pdf (18. VIII 2015).

L e h m a n n, Albrecht 2009. Homo narrans - Individuelle und kollektive Dimensionen des Erzählens. - Erzählkultur. Beiträge zur kulturwissenschaftlichen Erzählforschung. Toim R. W. Brednich. Berlin-New York: de Gruyter, lk 59-70.

L o t m a n, Juri 1990 [1981]. Kirjandus ja mütoloogia. - J. Lotman, Kultuurisemiootika. Tekst - kirjandus - kultuur. Tallinn: Olion, lk 317-346.

M a s i n g, Uku 2011 [1986]. Laen, uuslooming või relikt. - Aarded tellistes. Koost ja toim Mari-Liis Tammiste, Risto Järv, Kristi Salve. Tartu: Ilmamaa, lk 168188.

M e i e r, Moon 2012. Tänapäevase jutuvestmise mõtestamisvõimalusi: András Bereczki ja Terje Lillmaa seisukohad. Tartu: Tartu Ülikool, eesti ja võrdleva rahvaluule osakond. http://hdl.handle.net/10062/26096 (18. VIII 2015).

Niles, John D. 2010. Homo Narrans. The Poetics and Anthropology of Oral Literature. Philadelphia: University of Pennsylvania Press.

O lrik, Axel 1992 [1921]. Principles for Oral Narrative Research. Bloomington: Indiana University Press. 
Pr op p 1998 = Владимир Пропп, Кумулятивная сказка. - Поэтика фольклора. (Собрание трудов). Москва: Лабиринт.

P ä ä r, Piret 1999. Jutuvestmistraditsioon ja „Muinasjutukooli” osa selle säilitamisel. - Kuuldust-nähtust. (Tänapäeva folkloorist IV.) Toim Eda Kalmre. Tartu: Eesti Kirjandusmuuseum, lk 213-229.

$\mathrm{R}$ o t h, Klaus 2013. Narrating on the Internet. Digital communication as a problem of ethnology and folkloristics. - Linguistic World, kd 11, nr 2, lk 191-200.

RT Tuhkatriinu = Tuhkatriinu [lavastuse kodulehekülg]; http://www.rakvereteater.ee/teater/lavastus/tuhkatriinu/ (18. VIII 2015).

S c h e n d a, Rudolf 1993. Von Mund zu Ohr. Bausteine zu einer Kulturgeschichte volkstümlichen Erzählens in Europa. Göttingen: Vandenhoeck \& Ruprecht.

S c h mitt, Christoph 1999. Homo narrans: Studien zur populären Erzählkultur. Festschrift für Siegfried Neumann zum 65. Geburtstag. Toim C. Schmitt. Münster-New York: Waxmann.

SSTT 2010 [1968] = Sada saarelehte, tuhat toomelehte. Valimik eesti rahvajutte, -laule, mõistatusi ja vanasõnu. Koost Erna Normann, Selma Lätt. Tallinn: Koolibri.

St a h l, Sandra K. D. s.a. [1977]. Jutud isiklikest kogemustest. VTK raamat. http://www.folklore.ee/seminar (18. VIII 2015).

Z a vj a l o v a, Maria 2014. „Tibupoeg Pio” maagia ehk väärtusliku traditsioonilise teksti ootamatust esiletõusust. - Mäetagused. Hüperajakiri, nr 58, lk 35-52; www.folklore.ee/tagused/nr58/zavjalova.pdf (18. VIII 2015).

V a 1 k, Ülo 1998. Allilma isand. Kuradi ilmumiskujud eesti rahvausus. (Eesti Rahva Muuseumi sari 1.) Tartu: Eesti Rahva Muuseum.

V e n t o, Urpo 1980. Kerronta rituaalina. - Kertojat ja kuulijat. (Kalevalaseuran vuosikirja 60.) Toim Pekka Laaksonen. Helsinki: Suomalaisen Kirjallisuuden Seura.

VH 2009 = Valgõ härg. Kats tosinat seto jutust (ja üts viil liisna) / Valge härg. Kaks tosinat setu muinasjuttu (ja üks veel pealekauba). Kokko pand Risto Järv, toimõndanuq Paul Hagu ja R. Järv. Tartu: Tartu Ülikool, kultuuriteaduste ja kunstide instituut.

V i i d a l e p p, Richard 2004 [käsikirjas 1965]. Eesti rahvajuttude laadist, funktsioonist ja jutustajatest. (Sator 4.) Eesti Kirjandusmuuseumi rahvausundi töörühm. Tartu: Eesti Kirjandusmuuseum.

V ä lj a t a g a, Märt 2008. Narratiiv. - Keel ja Kirjandus, nr 8-9, lk 684-697.

Wi enker-Piepho, Sabine 1993. Sub Kettenmärchen. - Enzyklopädie des Märchens. Handwörterbuch zur historischen und vergleichenden Erzählforschung. Kd 7. Berlin-New York: de Gruyter, lk 1194-1201. 
Keywords: folk narrative, formula tale, fieldwork, personal story

The introductory article of the special issue on folk narratives includes a chain tale „Peas Won't Go into Bag”, classifiable under the tale type ATU 2030, where in order to get things right a funny piece of violence is required to be enacted on increasingly bigger recusant animals. This is a cumulative story told to the author of the article by a special informant met at a tale-collecting fieldwork. There is nothing unusual in story-telling, despite the frequently idealized portrayals of the great story-tellers of old, sometimes deliberately contrasting with the modern tradition. Actually, most of us are able to produce a tale or two even today, especially stories of personal experience. As personal stories are, however, strongly rooted in tradition there is never an end either to topics or to storytelling, which makes folk narration, in essence, an endless process.

A folk tale is a juncture of two seemingly opposite planes - one analytical and informative, the other poetic and visionary. Narrative poetics enables the conveyance of different types of information by a skilful and creative use of imagery. Hence the necessity of dwelling upon some key concepts of folk tale poetics, such as simplicity and memorability, genre requirement or code, associations with real life, even in the case of apparently unreal topics (like in fairy tales), and the message of a story, which depends on the context of the narration. Throughout times, many of the folk tales have been based on rumour and gossip, while the opposite end of the everyday axis points to the classical „valuable" genres such as legend, fairy tale and myth, with the everyday story (Gm Alltagsgeschichte) sitting somewhere in between. Earlier folklorists would use a static text-centered approach, which by to-day has mostly been replaced by one regarding folklore as a process, hence the choice of the authors for the special issue. However, although text-centered analysis requires folk tales to be captured on paper, which is somewhat like the above attempt to force peas into a bag, with some unavoidable violence involved, it is not unfeasible after all.

Risto Järv (b. 1971), PhD, Estonian Literary Museum, Estonian Folklore Archives, Head of the Archives; University of Tartu, Department of Estonian and Comparative Folklore, Associate Professor of Estonian Folklore, risto@folklore.ee 